DO PEOPLE MAKE THE PLACE?: AN EXAMINATION OF
THE ATTRACTION-SELECTION-ATTRITION HYPOTHESIS

ROBERT D. BRETZ, JR.

Cornell University

Working Paper \# 88-16

RONALD A. ASH

GEORGE F. DREHER

University of Kansas

University of Indiana

Center for Advanced Human Resource Studies

New York State School of Industrial and Labor Relations

393 Ives Hall

Cornell University

Ithaca, New York 14851-0952

607-255-2742

This paper has not undergone formal review or approval of the faculty of the ILR School. It is intended to make the results of Center research, conferences, and projects available to others interested in human resource management in preliminary form to encourage discussion and suggestions. 


\title{
Homogeneity 2
}

\section{DO PEOPLE MAKE THE PLACE? AN EXAMINATION OF THE ATTRACTION-SELECTION-ATIRITION HYPOTHESIS}

\begin{abstract}
This study tests the hypotheses that (1) congruence between internal need states and external environments drives the organizational-choice process, and (2) those attracted to particular organizations are more homogeneous than the applicant pool in general. Subjects were evaluated on fourteen needs using the Jackson Personality Research Form. They then viewed two video-taped segments of simulated campus interviews to gain information about two distinct organizational types. The interview segments entered the discussion inprogress to avoid any reference to a particular job which might introduce an occupational confound. Subjects received job offers from both organizations and were asked to indicate which of the two organizations they found more attractive by accepting one of the offers. Analysis of variance results indicated only weak support for the congruency hypothesis. Differences were observed in $\mathrm{n}$ Ach between the groups of subjects attracted to each organization. No differences were found for any of the other need strength measures. This suggests that the subjects attracted to the different organizations are substantially similar. Implications for the homogeneity hypothesis are discussed and suggestions for further study of this concept are offered.
\end{abstract}




\section{DO PEOPLE MAKE THE PLACE?: AN EXAMINATION OF THE ATIRACTION-SELECTION-ATTRITION HYPOTHESIS}

Schneider $(1983,1987)$ has argued that over time, forces within an organization operate to attract, select, and retain an increasingly homogeneous group of employees. These individuals are hypothesized to share common backgrounds, characteristics, and orientations. As a result of this homogeneity, organizations are expected to become less able to respond to changes, threats, and opportunities in the external environment. Because of this, the organization enters a period of stagnation. Unless the powers that operate to create and perpetuate homogeneity are combated, stagnation will be followed by decline and eventual demise (Schneider, 1983).

Organizations routinely engage in activity to identify and select individuals from the applicant population that are somewhat homogeneous. By relying on established recruiting sources (e.g. specific universities for college recruiting), and established screening and selection techniques (e.g. specific tests and minimum cut-off scores), organizations narrow the range of characteristics chosen applicants are likely to possess. In doing so, it appears that organizations often attempt to create, rather than stifle, homogeneity.

Interactional psychology suggests how naturally occurring interactions between persons and settings operate to shape behavior (Bowers, 1973). This behavior in turn determines the organizational environment. Schneider (1987) develops an attraction-selection-attrition framework on the basis of interactionist ideology, and sets forth a series of propositions that suggest how homogeneity may develop as a result of these naturally occurring 
interactions. While these propositions appear to be based on sound theoretical principles, there exists no known empirical investigation of the extent to which homogeneity exists among those attracted to the organization, those selected by the organization, or those retained in the organization. This study attempts empirical investigation of the homogeneity hypothesis at the attraction phase of the cycle.

\section{Organizational Search and Choice}

The degree to which individuals find organizations to be attractive is central to the organizational search and choice literature. The manner in which individuals evaluate and choose between available job alternatives has been studied in a number of ways. Economic debate over the processes used has focused on discussion of whether the choice follows a rational or irrational model (e.g. Parnes, 1954; Rottenberg, 1956). Direct estimation procedures have asked potential employees to rank or rate several predetermined job attributes in terms of their importance to the job choice (Jurgensen, 1978). Expectancy theory methodologies have used both between-subject, and within-subject applications to capture applicants' decision-making models in mathematical expressions (Arnold, 1981; Einhorn, 1971; Feldman \& Arnold, 1978; Fischer, 1976; Huber, Daneshgar \& Ford, 1971; Singh, 1975; Stahl \& Harrel1, 1981; Strand, Levine, and Montgomery, 1981; Rynes, 1981; Rynes, Schwab \& Heneman, 1983, and Zedeck, 1977). Unfortunately, though this research concerns itself with identifying subjects' attraction to organizations, it does not test the homogeneity question since subjects are not classified. As the notable exception, Zedeck (1977) used policy-capturing combined with "judgment analysis clustering" to classify subjects into groups on the 
basis of similarity between their individual policy equations. His results suggest that subjects who are alike in their job choice decision making processes also display similarity on certain biographical factors (e.g. age, sex, college major, and work experience). This result is important here since Zedeck has shown that organizational characteristics influence the organizational-choice process differently for different identifiable groups of people.

A small body of literature addresses the role of congruence between person and setting in organizational choice. This handful of studies draws primarily on two theories from the occupational choice literature. Super (1953) views a person's career as a synthesis of the person's self concept and the realities of the occupational environment. Holland (1966) also assumes that personsituation congruence will drive the vocational choice. He hypothesizes an interaction between the individual's personality and the environment offered by the occupation. Organizational choice can be seen as the first step a person takes to implement an occupational choice (Keon, Latack, and Wanous, 1982). Since homogenization resulting from an attraction-selection-retention cycle is theoretically based on the interactionist notion of naturally occurring interactions between individuals and settings, the vocational choice theories that predict occupational choice on the basis of person-environment congruence are particularly applicable.

Tom (1971) extended Super's (1953) proposition that vocational development is a process of implementing one's self concept by applying Super's theory to the problem of organizational choice. Tom asked subjects to describe themselves and two organizations: one they would most prefer to work for and one they would least prefer to work for. He found that the similarity 


\section{Homogeneity 6}

between how an individual described himself and how he described the organization he most preferred to work for was greater than the similarity between how he described himself and how he described the organization he least preferred to work for.

A more recent application of person-environment congruence to organizational choice concerns the choice of a graduate school. Keon, Latack, and Wanous, (1982) examined the relationship between self-image and organizational choice. Previous research suggests that occupational choice and self-image are related (Korman, 1966). The authors report that this result extends to organizational choice as well. Within-subject correlational analysis between self-image and school image showed that for subjects with positive self-image, the greater the congruence between organization image and self-image, the more attractive the organization was. For subjects with negative self-image, less congruence between organization image and self-image was associated with higher levels of attractiveness. Since conflicting results are offered, little can be concluded about the drive to seek congruence.

Noting the relationship between Type A behavior and several negative consequences, Burke and Deszca (1982) investigated the relationship between Type A behavior in graduating students and preference for particular organizational climates. Personality attributes used to describe Type A individuals include: ambition, competitiveness, hostility, need for achievement, and impatience. Type A behavior scores were related to working environments characterized by high performance standards, spontaneity, ambiguity, and toughness. The results are supportive of the individualenvironmental congruency hypothesis. 


\section{Homogeneity 7}

Ellis and Taylor (1983) studied the role of self-esteem in the job search process. Subjects' self-esteem was measured prior to the job search process. After four months of job search activity several relationships between selfesteem and search/outcome activity were noted. Self-esteem was related to sources used. Subjects with low self-esteem used more formal informational sources. Self-esteem was related to evaluation by interviewers. Subjects with higher self-esteem received better evaluations. Self-esteem was also related to several outcome variables. Number of job offers, acceptance of a position, and intended job tenure were all positively related to self-esteem. While this research does not examine the person-environment congruency issue, per se, it does provide support for Super's (1953) contention that self-image influences an individual's decision making process.

Turning to Holland's (1966) theory of personality congruence, Niener and Owens (1985) used biographical data to predict job choice. Entering freshmen provided biographical data. Several years after graduation these same subjects completed a questionnaire describing their job. Jobs were then classified into one of the six Holland occupational types (artistic, investigative, conventional, realistic, social, or enterprising). Discriminant analysis explained $24 \%$ of the variation in job type for males and $20 \%$ for women. Chance level is $16.67 \%$. The results suggest that a person's background and opportunity for skill and ability development do appear to influence both occupational and organizational choice. The authors suggest that this supports Holland's congruency hypothesis.

The realistic job preview (RJP) literature is also based on congruency (e.g. Wanous, 1980). It posits that displaying an accurate preview of the job both reduces unrealistic expectations and allows applicants to self-select 
out of incongruent environments. Unfortunately, this literature has focused on job characteristics and has not yet considered the impact of organizational information on applicants' attraction to particular organizations.

Taken as a whole, this literature suggest that the occupational choice framework appears to have merit for organizational choice as well. However, while these studies indicate that individuals may seek congruence between internalized characteristics and external conditions and thereby suggest support for the homogeneity hypothesis, they fall short of actually testing the degree to which individuals attracted to an organization are more or less alike than the population from which they were drawn. This study attempts to do that. If homogeneity exists at the attraction stage, initial support is indicated for the congruency and homogeneity hypotheses. If however, individuals attracted to particular organizations do not share common characteristics, the negative consequences resulting from increasing homogeneity appear less likely.

\section{Hypotheses}

Schneider (1987) suggests describing organizations in terms of what they reward, support, and expect. He further suggests that personality measures may be useful in determining which types of individuals are attracted to which types of organizations. Two personality dimension in particular seem to offer the highest potential for examining both the congruency and the homogeneity questions. The characteristics that describe need for achievement (n Ach), include a focus on individual effort and achievement, competitive disposition, and a contest orientation toward mobility and reward allocation. These characteristics are highly congruent with reward systems characterized by 
merit pay, individual performance appraisal, and promotion on the basis of proven ability. Alternatively, the characteristics that describe need for affiliation ( $\mathrm{A}$ Aff), include a desire for high levels of interaction, and a cooperative disposition. These characteristics are highly congruent with reward systems which encourage high degrees of cooperative work effort and distribute rewards on the basis of organizational performance through practices such as profit-sharing and bonuses.

If vocational choice theories apply in the organizational attractiveness context, directional hypotheses are possible. In particular, subjects finding the individually-oriented system more attractive should display higher need for achievement while those finding the organizationally-oriented system more attractive should display higher need for affiliation.

However, the homogeneity question is not dependent upon the congruency hypothesis. To test for homogeneity, the hypothesis need merely state that within group differences on individual characteristics (such as, but not limited to $\mathrm{n}$ Ach and $\mathrm{n}$ Aff) will be smaller than differences observed in the entire sample on these individual attributes. The groups of interest are defined by the choice of one organization or the other as described in the following section.

\section{Method}

To test for homogeneity it is first necessary to obtain measures of individual differences. The Jackson Personality Research Form (PRF) was used to assess subjects on their needs for achievement, affiliation, aggression, autonomy, dominance, endurance, exhibition, harm avoidance, impulsivity, nurturance, order, play, social recognition, and understanding. The PRF was 
chosen over other measures of individual differences because it is firmly grounded in interactionist psychology by virtue of its direct association with Murray's (1938) model and taxonomy of person-setting interaction. The PRF is specifically designed to assess the personality dimensions formulated by Murray. Murray's original trait definitions have been reformulated in light of new theoretical and empirical developments, but the PRF follows directly from Murray's framework and remains true to Murray's apparent intent.

The PRF also displays better psychometric properties than other tests of this type (Anastasi, 1972). Odd-even reliability coefficients range from .48 to $.90 ; \mathrm{K}-\mathrm{R} 20$ coefficients range from .54 to .86 ; and test-retest coefficients range from .69 to .90 . Additionally, the PRF has received consistently favorable critiques by subject matter experts (Buros, 1972, 1978).

Once individual differences are known, it is necessary to determine which organizations are attractive to which individuals. Two organizational types were created. One represented an environment that encouraged and rewarded individual behavior. The other encouraged and rewarded effort directed at the organization's collective wellbeing (Staw, 1986). Characteristics of each system are presented in Table 1.

\section{Table 1 Here}

Four video-taped segments of simulated campus interviews were created by crossing the two organizational types with two interviewers. Since the subjects would be viewing video-taped interview segments from both organizations, two interviewers were needed to create a more realistic manipulation. The interviewers' appearance and dress were matched as closely 
as possible and the design was balanced to minimize interviewer and order affects. The applicant in each tape was played by the same person. The applicant's responses were video-taped one time and edited into each tape in order to minimize variations on her part.

Recall that the vocational choice literature offers substantial empirical evidence to suggest that particular types of people are attracted to specific occupations (e.g. Super, 1953; Holland, 1966). Therefore, any methodology that makes reference to a particular occupation risks confounding occupational choice with attraction for the particular organization. Most interview methodologies require reference to a particular job. To avoid this problem, the video-tapes used here enter the interview in-progress at a point where the applicant is asking the interviewer questions about the nature of the organization. The interviewer responds in a fashion consistent with the points outlined in Table 1 . Since the video-tape enters the interview in-progress, subjects are free to, and are encouraged to assume that the job in question is consistent with their occupational preferences. Therefore, organizational attractiveness, independent of occupational attributes should influence the subjects' perceptions and subsequent decisions.

To measure organizational attractiveness, subjects received job offers from both of the organizations portrayed in the interviews, and were asked to indicate which of the two they would rather join by accepting one of the offers. Subjects were reminded that the choice of one of the two companies precluded the other from any further consideration. This is a better measure of attractiveness than the more commonly used rating scales since it imposes a cost on the subject in the form of lost opportunity. It is also much more realistic and precludes the subjects from considering the alternatives to 
be equally attractive; an outcome that is common in procedures that ask applicants to rate the attractiveness of each organization.

\section{Subjects}

Students approaching graduation, many of whom were currently engaged in the process of campus recruiting, were used as subjects. Subjects were enrolled in either an upper-level personnel management course or in an upperlevel theory of the interview course at a large midwestern university. All subjects received course credit for participating. Subjects were mostly seniors $(92 \%)$ enrolled in either the school of business $(41 \%)$ or the college of liberal arts and sciences (53\%). The sample was $54 \%$ male and many areas of occupational interest were represented: human resource management (27\%), sales $(19 \%)$, general management $(17 \%)$, accounting $(9.5 \%)$, marketing ( $8.5 \%)$, and finance $(4 \%)$. The remainder of the sample indicated overlapping areas of interest or diverse areas such as ministry, farming, or law.

Power analysis indicated that in order to detect a moderate effect $(f=.25$; where $f$ is the standard deviation of the standardized group means) with a power of .80 , an alpha level of .05 , a minimum sample size of 144 is required (Cohen, 1977). A total of 211 subjects completed the experiment therefore sample size is considered adequate.

\section{Procedure}

The video-tapes were pilot tested to insure that (1) the message intended to be conveyed by the tapes was actually being received, (2) the subjects were sufficiently able to put themselves into the role of the applicant and remove the possible occupational confound, and (3) any interviewer affect 
would be minimized. Subjects viewed either the video-tape conveying individually-oriented information or the video-tape conveying organizationallyoriented information. They then responded to a questionnaire asking them to indicate the likelihood $(1=$ very unlikely to $5=$ very likely) of the organization engaging in specific activities (e.g. How likely is it that this organization would have a profit-sharing plan?). The responses to the individually-oriented questions were averaged to form the variable Individual System and the responses to the organizationally-oriented questions were averaged to form the variable Organizational System. Similarly, responses to questions about the interviewer were average to form the variable Interviewer Effect and responses to questions about the subjects' ability to place themselves in the role of the applicant were averaged to form the variable Occupational Confound. The greater the subjects' ability to assume that the interview in question was one in their area of interest, the more likely it is that the occupational confound was removed.

Table 2 shows that the manipulations were achieved, and that the occupational confound was controlled. The pilot study also indicated a marginally significant interviewer affect. To control for this the design was balanced so that an equal number of subjects viewed each organization being represented by each interviewer.

\section{Table 2 Here}

The experiment consisted of two phases. In the first phase, the PRF was administered. In the second phase, subjects were informed of the procedure that would follow and were given the opportunity to ask questions about the 
Homogeneity 14

process. They were then told to listen carefully to the information in the video-tapes, to try to imagine that the job in question was one in their area of interest, to try to place themselves in the role of the applicant, and to be prepared to answer questions about the tapes upon their completion. Each tape lasted about five minutes.

Upon completion of the tapes, subjects were given a fact sheet telling them that the organizations they had just previewed were essentially alike in regard to reputation, location, career opportunity and salary levels. They were informed that both had job openings in their area of interest, and that they would receive job offers from both organizations. They were then asked to consider the information presented in the video-tapes and choose one organization over the other (i.e. accept one of the job offers) realizing that doing so precluded the not-chosen organization from any further consideration.

A manipulation check questionnaire was then completed. The results are presented in Table 3 . The results are similar to those found in the pilot study. The manipulations were powerfully achieved and the occupational confound was controlled. An interviewer affect was noted but since the means were both highly favorable and the design was balanced, it does not represent a significant problem.

\section{Table 3 Here}

\section{Analysis}

In the initial analysis, $\mathrm{n}$ Ach and $\mathrm{n}$ Aff were used as the dependent variables and organization chosen was used as the independent variable. The 
issue of concern is whether there are identifiable differences on the individual measures between the subgroups determined by organizational choice. Analysis of variance (ANOVA) is used to test the hypothesis.

Discriminant function analysis was also used to test whether any possible combination of scores on the fourteen need strength measures derived from the PRF would predict organizational choice. Since choice indicates the relative attractiveness of the two alternatives, a constellation of need strength scores that predict choice would be indicative of a tendency toward homogeneity at the attraction stage.

\section{$\underline{\text { Results }}$}

Preliminary results suggested only weak support for the directional hypothesis that the drive for congruence would cause those with a high need for achievement to find the individually-oriented system to be more attractive, and those with a high need for affiliation would find the organizationallyoriented system to be more attractive. ANOVA results show a weak effect for $\mathrm{n}$ Ach $(\mathrm{F}=3.177, \mathrm{p}=.076)$ indicating that $\mathrm{n}$ Ach scores tended to be higher among subjects attracted to the individually-oriented system than they did among subjects attracted to the organizationally-oriented system. However, no differences were noted on $\mathrm{n}$ Aff between the two groups of subjects $(\mathrm{F}=$ $.101, \mathrm{P}=.750$ ) indicating that subjects who find the individually-oriented system to be more attractive exhibit the same need for affiliation as do those attracted to the organizationally-oriented system. Complete ANOVA results are given in Table 4. 
Table 4 Here

Even though no directional hypotheses were offered in regard to how the other twelve needs measured by the PRF might influence perceived attractiveness, they were examined using discriminant function analysis to determine if differences on need strengths could predict organizational preference at a level greater than chance. The discriminant function was only able to correctly classify $60 \%$ of the subjects on the basis of their need strength profiles. This result is well within the probability limits of occurring by chance (Chi squared $=15.25, \mathrm{p}=.437$ ). Results of the discriminant analysis are given in Table 5 .

Table 5 Here

Table 6 shows the mean scores and standard deviations for all need strengths for the combined sample and for the subsamples preferring each of the two organizations. There are no significant differences noted between the groups on any of the characteristics with the exception of $\mathrm{n}$ Ach. It appears that the subjects attracted to the individually-oriented system are very similar to those attracted to the organizationally-oriented system. In the absence of significant differences, it is not surprising that the discriminant function was unable to predict at better than chance level. 
Table 6 Here

\section{Discussion}

The results found here indicate weak support for the congruency hypothesis suggested by the occupational choice literature. Because the characteristics that describe high need for achievement also seem to describe an individuallyoriented organizational atmosphere, sound arguments can be made for expecting those with a high need for achievement to be attracted to environments that encourage and reward competitive, individual effort and accomplishment. It appears that to a limited degree the subjects in this study did self-select on the basis of $\mathrm{n}$ Ach. There was not however any effect noted for $\mathrm{n}$ Aff, thus precluding a strong argument in favor of homogeneity on the basis of drive for congruence.

What is perhaps more revealing is the inability of the discriminant function to predict organizational preference on the basis of the entire need constellation provided by the PRF. While is it clear that need strengths are but one scheme upon which individuals may be classified (e.g. Owens and Schoenfeldt, 1979), they were chosen as the defining characteristics here because of their role in the interactionist ideology: People with similar needs are attracted to particular settings and tend to stay in those settings if their needs are met. Failure to find any meaningful combination of need 
strengths that predict organizational preference casts doubt on the legitimacy of the homogeneity hypothesis at the attraction phase.

Homogeneity can be detected in two ways. First, as with $\mathrm{n}$ Ach, the means between the two groups may be significantly different indicating that the characteristic in question is present to a greater degree in one group than in the other. However, absence of mean differences does not necessarily negate the possibility of homogeneity within the groups. It is possible that the means could be similar but that the degree of dispersion around the means might differ. This being the case, comparison of within group variances is indicated. Examination of the standard deviations in Table 6 reveals that the variances on these characteristics between organizations are also substantially similar. These arguments suggest that for this sample, the subjects attracted to one organization do not appear to be much differeni than those attracted to the other.

Schneider (1987) downplayed the significance of experimental laboratory research on the basis that it generally included the random assignment of subjects to conditions and thereby subverted the interactionist ideology that people self-select into and out of situations. He also suggested that the use of personality measures "should be useful for identifying the types of people who cluster in different organizations". This research has attempted to address those concerns and yet can not offer much support for Schneider's hypotheses. Perhaps other personality measures might offer different results but this is unlikely given the psychometric properties of the PRF vis a vis other instruments of this type (Buros, 1972, 1978).

The method in which organizations are described should also influence the degree to which individuals self-select. The organizations in this study 
were described mainly in terms of their reward systems. The systems were described such that their internal characteristics were highly congruent and differences between what the two organizations reward, support, and expect were maximized. The manipulation check suggested that subjects were able to comprehend the differences between the systems described, so failure to find homogeneity can not be assigned to a misunderstanding of the organizational conditions.

The experimental design used here focused subjects' attention on a highly visible and important organizational dimension that is (1) likely to be known by applicants at the time they make job choices, and (2) theoretically linked to person-situation congruence. Furthermore, Schneider (1987, p. 448) suggests that organizations can be classified on the basis of what they "reward, support, and expect". The reward systems used in this study follow Schneider's recommendation by conveying information about what is important to the organizations. However, since other organizational characteristics also influence attractiveness, the homogeneity hypothesis cannot be rejected outright on the basis of these results. This research represents the first empirical investigation of the hypothesis and should serve as a model upon which future research can build to more completely test the legitimacy of the homogeneity hypothesis. Since this research has called into question homogeneity among a group of attracted subjects, more research using different individual measures and different organizational characteristics is called for.

The use of student subjects may represent a problem. While this was not truly a convenience sample since the hypotheses apply to entry level positions and the degree of organizational attractiveness at that stage, there 


\section{Homogeneity 20}

are some problems associated with using student subjects. The major concern is that the majority of these subjects have never held a full-time job and many have not worked even part-time for more than one employer. Because of this, the concerns that others have voiced about the ability of student subjects to understand the message conveyed in the manipulation may be a problem here (e.g. Rynes, Heneman, and Schwab, 1980; Schwab, 1982). The argument is that because student subjects have so little job experience on which to draw, the relevant job- or organization-specific attributes conveyed in the manipulations may be irrelevant.

Given the magnitude of the $F$ statistics in the manipulation check, there can be no question that the subjects understood the differences between the organizations. However, given their lack of experience, they may have understood the differences but may not have known what working under each type of system would really be like. Further research with more experienced subjects may yield different results.

The homogeneity question deserves further research. Different subject pools (such as the use of non-student populations) is just one area of possible exploration. The question should also be tested in field studies that actually examine the types of people that apply at different organizations. This would require in-depth analysis of the information that the applicant has about the organization at the time of application as well as analysis of some individual characteristics. This will only be an improvement over a laboratory study if we are able to ascertain what applicants know, or think they know about the organization when they apply. A cross-sectional approach could also be used to examine homogeneity within an organization. If it is true that homogeneity develops over time, one would expect lower levels of 
homogeneity at the entry level, increasing amounts at middle levels, and the greatest amount at upper levels. Comparisons of mean and variance differences on individual characteristics at different organizational levels may be enlightening. 


\section{References}

Anastasi, A. (1972). Critique of PRF in Buros, O.K. The seventh mental measurements yearbook. Highland Park, NJ: Gryphon Press.

Arnold, H.J. (1981). A test of the validity of the multiplicative hypothesis of expectancy-valence theories of work motivation. Academy of Management Journal, $\underline{24}$ (1), 128-141.

Bowers, K.S. (1973). Situationism in psychology: An analysis and critique. Psychological Review, 80, 307-336.

Burke, R.J. and Deszca, E. (1982). Preferred organizational climates of Type A individuals. Journal of Vocational Behavior, 21, 50-59.

Buros, 0.K. (1972). The seventh mental measurements yearbook. Highland Park, NJ: Gryphon Press.

Buros, O.K. (1978). The eighth mental measurements yearbook. Highland Park, NJ: Gryphon Press.

Einhorn, H.J. (1971). Use of nonlinear, noncompensatory models as a function of task and amount of information. Organizational Behavior and Human Performance, $\underline{6}, 1-27$.

Ellis, R.A. and Taylor, M.S. (1983). Role of self-esteem within the job search process. Journal of Applied Psychology, 68 (4), 632-640.

Feldman, D.C. and Arnold, H.J. (1978). Position choice: Comparing the importance of organizational and job factors. Journal of Applied Psychology, 63 (6), 706-710.

Fischer, G.W. (1976). Multidimensional utility models for risky and riskless choice. Organizational Behavior and Human Performance, 17, 127-146.

Holland, J.L. (1966). The Psychology of Vocational Choice. New York: Blaisdell. 
Huber, G.P., Daneshgar, R., and Ford, D.L. (1971). An empirical comparison of five utility models for predicting job preferences. Organizational Behavior and Human Performance, $\underline{6}, 267-282$.

Jurgensen, C.E. (1978). Job preferences (What makes a job good or bad?). Journal of Applied Psychology, 63 (3), 267-276.

Keon, T.L., Latack, J.C., and Wanous, J.P. (1982). Image congruence and the treatment of difference scores in organizational choice research. Human Relations, 35 (2), 155-166.

Korman, A.K. (1966). Self-esteem variable in vocational choice. Journal of Applied Psychology, 50, 479-487.

Murray, H.A. (1938). Explorations in personality. New York: Oxford University Press.

Neiner, A.G. and Owens, W.A. (1985). Using biodata to predict job choice among college graduates. Journal of Applied Psychology, 70 (1), 127136.

Owens, W.A. and Schoenfeldt, L.F. (1979). Toward a classification of persons. Journal of Applied Psychology Monograph, 65 (5), 569-607.

Parnes, H.S. (1954). Research on labor mobility: An appraisal of research findings in the United States. New York: Social Science Research Council.

Rottenberg, S. (1956). On choice in labor markets. Industrial and Labor Relations Review, 9 , 183-199.

Rynes, S.L. (1981). Evaluation of job alternatives in the context of seeking employment. Unpublished doctoral dissertation, University of Wisconsin. 
Rynes, S.L., Heneman, H.G., and Schwab, D.P. (1980). Individual reactions to organizational recruiting: A review. Personnel Psychology, 33, 529542 .

Rynes, S.L., Schwab, D.P., and Heneman, H.G. (1983). The role of pay and market pay variability in job application decisions. Organizational Behavior and Human Performance, 31, 353-364.

Schneider, B. (1983). An interactionist perspective on organizational effectiveness. In K.S. Cameron and D.A. Whetton (Eds.), Organizational Effectiveness: A Comparison of Multiple Models. Orlando, FL: Academic Press.

Schneider, B. (1987). The people make the place. Personnel Psychology, 40, (3), 437-453.

Schwab, D.P. (1982). Recruiting and organizational participation. In K.M. Rowland and G.R. Ferris (Eds.), Personnel Management, 103-127. Boston: Allyn and Bacon, Inc.

Singh, R. (1975). Information integration theory applied to expected job attractiveness and satisfaction. Journal of Applied Psychology, 60 (5), $621-623$

Stahl, M.J. and Harrell, A.M. (1981). Modeling effort decisions with behavioral decision theory: Toward an individual differences model of expectancy theory. Organizational Behavior and Human Performance, 27, 303-325.

Staw, B.M. (1986). Organizational psychology and the pursuit of the happy/productive worker. California Management Review, 28 (4), 40-53. Strand, R., Levine, R., and Montgomery, D. (1981). Organizational entry preferences based upon social and personal policies: An information 
integration perspective. Organizational Behavior and Human Performance, 27, 50-68.

Super, D.E. (1953). A theory of vocational development. American Psychologist, $\underline{8}, 185-190$.

Tom, V.R. (1971). The role of personality and organizational images in the recruiting process. Organizational Behavior and Human Performance, $\underline{6}$, 573-592.

Wanous, J. (1980). Organizational entry: Recruitment, selection, and socialization of newcomers. Reading, Mass: Addison-Wesley.

Zedeck, S. (1977). An information processing model and approach to the study of motivation. Organizational Behavior and Human Performance, 18, 4777 . 
Table 1

Individual and Organizational system characteristics.

\section{INDIVIDUALLY-ORIENTED SYSTEM CHARACTERISTICS}

1. Extrinsic rewards tied to individual performance.

2. Individual-specific realistic and challenging goals.

3. Individual performance evaluated and timely feedback given.

4. Promotions made on the basis of individual skill and performance.

5. Skill level in workforce built through training and development.

6. Jobs designed to increase responsibility, variety, and significance.

\section{ORGANIZATIONALLY-ORIENTED SYSTEM CHARACTERISTICS}

1. Job rotation common so that company loyalty replaces unit loyalty.

2. Company-specific training reduces market opportunities and increases value within the organization.

3. Long-term employment through explicit or implicit contracts increase company loyalty.

4. Decentralized structure with few departments to compete for the loyalty of employees.

5. Few status distinctions between organizational levels.

6. Individual rewards tied to organizational performance through profit sharing, bonuses, stock options.

Source: Staw, 1986. Citation in text. 
Table 2

Pilot study means and ANOVA significance for power of manipulation, occupational confound, and interviewer.

ANOVA 1: DIFFERENCES BY ORGANIZATIONAL TYPE

INDIVIDUAL SYSTEM ORGANIZATIONAL SYSTEM INTERVIEWER EFFECT OCCUPATIONAL CONFOUND

\begin{tabular}{llllll}
\multirow{2}{*}{$\begin{array}{c}\text { GRAND } \\
\text { MEAN }\end{array}$} & \multicolumn{2}{l}{ MANIPULATION } & & $F$ & $\mathrm{p}$ \\
\cline { 2 - 3 } & IND. & ORG. & & \\
\hline 3.45 & 4.29 & 2.58 & $\frac{103.31}{67.13}$ & .000 \\
3.85 & 3.28 & 4.45 & $\frac{670}{1.92}$ & .172 \\
4.19 & 4.11 & 4.28 & .01 & .933 \\
3.69 & 3.69 & 3.68 &
\end{tabular}

ANOVA 2: DIFFERENCES BY INTERVIEWER

INDIVIDUAL SYSTEM ORGANIZATIONAL SYSTEM INTERVIEWER EFFECT OCCUPATIONAL CONFOUND

\begin{tabular}{ccccc}
$\begin{array}{r}\text { GRAND } \\
\text { MEAN }\end{array}$ & $\begin{array}{c}\text { INTVR } \\
\# 1\end{array}$ & $\begin{array}{c}\text { INTVR } \\
\# 2\end{array}$ & F & p \\
\hline 3.45 & 3.45 & 3.45 & .03 & .864 \\
3.85 & 3.92 & 3.80 & .43 & .513 \\
4.19 & 4.06 & 4.30 & 3.78 & .058 \\
3.69 & 3.69 & 3.68 & .01 & .909
\end{tabular}


Table 3

Manipulation check means and ANOVA significance for power of manipulation, occupational confound, and interviewer effect.

ANOVA 1: DIFFERENCES BY ORGANIZATIONAL TYPE

INDIVIDUAL SYSTEM ORGANIZATIONAL SYSTEM INTERVIEWER EFFECT OCCUPATIONAL CONFOUND

$\begin{array}{rlll}\text { GRAND } & \text { MANIPULATION } & F & p\end{array}$

\begin{tabular}{lllll}
\hline 3.38 & 4.40 & 2.40 & $\frac{557.13}{458.45}$ & .000 \\
3.68 & 2.93 & 4.40 & $\frac{450}{13.01}$ & .000 \\
4.07 & 3.94 & 4.20 & $\frac{1.00}{.23}$ & .629
\end{tabular}

ANOVA 2: DIFFERENCES BY INTERVIEWER

INDIVIDUAL SYSTEM ORGANIZATIONAL SYSTEM INTERVIEWER EFFECT OCCUPATIONAL CONFOUND

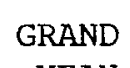

MEAN

3.38

3.68

4.07

3.66
INTVR

\#1

INTVR
$\# 2$

3.38

3.67

3.98

3.63
3.38

3.69

4.17

3.69
F p

nen

$\begin{array}{rr}.02 & .898 \\ .15 & .698 \\ 6.96 & .009 \\ .30 & .586\end{array}$


Table 4

ANOVA results for congruency hypothesis and homogeneity test.

\begin{tabular}{|c|c|c|c|c|c|}
\hline Source of Variation & Sum of $S Q$ & $\mathrm{DF}$ & Mean SQ & $F$ & $\mathrm{p}$ \\
\hline & \multicolumn{3}{|c|}{$\mathrm{n}$ Ach } & & \\
\hline MAIN EFFECTS & 268.211 & 1 & 268.211 & 3.177 & .076 \\
\hline Company Chosen & 268.211 & 1 & 268.211 & 3.177 & .076 \\
\hline Explained & 268.211 & 1 & 268.211 & 3.117 & .076 \\
\hline Residual & 17642.281 & 209 & 84.413 & & \\
\hline Total & 17910.493 & 210 & 85.288 & & \\
\hline \multicolumn{6}{|l|}{ Multiple $\mathrm{R}^{2}=.015$} \\
\hline Multiple $\mathrm{R}=.122$ & & & & & \\
\hline \multicolumn{6}{|c|}{$n$ Aff } \\
\hline MAIN EFFECTS & 9.419 & 1 & 9.419 & .101 & .750 \\
\hline Company Chosen & 9.419 & 1 & 9.419 & .101 & .750 \\
\hline Explained & 9.419 & 1 & 9.419 & .101 & .750 \\
\hline Residual & 19413.140 & 209 & 92.886 & & \\
\hline Total & 19422.559 & 210 & 92.488 & & \\
\hline \multicolumn{6}{|l|}{ Multiple $\mathrm{R}^{2}=.000$} \\
\hline Multiple $\mathrm{R}=.022$ & & & & & \\
\hline
\end{tabular}


Table 5

Discriminant function analysis of organization chosen.

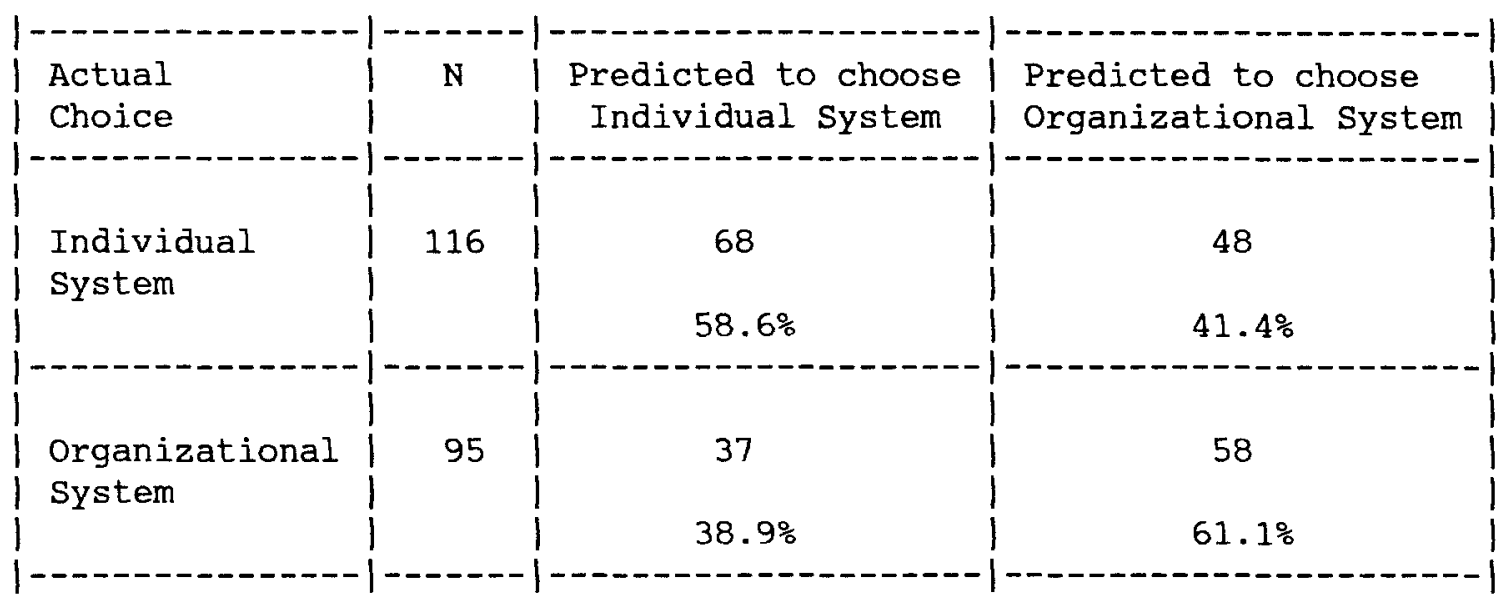

Percent correctly classified: $59.72 \%$

Chi-Square: $15.250, \mathrm{p}=.437$ 
Table 6

Differences in need strengths mean scores by organization chosen.

\begin{tabular}{|c|c|c|c|c|c|}
\hline Need & $\begin{array}{l}\text { Grand } \\
\text { Mean }\end{array}$ & $\begin{array}{l}\text { Ind } \\
\text { Mean }\end{array}$ & $\begin{array}{l}\text { Org } \\
\text { Mean }\end{array}$ & F & $p$ \\
\hline Achievement & $\begin{array}{l}55.11 \\
(9.2)\end{array}$ & $\begin{array}{l}56.13 \\
(9.3)\end{array}$ & $\begin{array}{l}53.86 \\
(9.0)\end{array}$ & 3.177 & .076 \\
\hline Affiliation & $\begin{array}{l}54.60 \\
(9.6)\end{array}$ & $\begin{array}{l}54.79 \\
(9.7)\end{array}$ & $\begin{array}{l}54.37 \\
(9.6)\end{array}$ & .101 & .751 \\
\hline Aggression & $\begin{array}{l}52.829 \\
(8.4)\end{array}$ & $\begin{array}{l}52.81 \\
(9.5)\end{array}$ & $\begin{array}{l}52.85 \\
(6.8)\end{array}$ & .001 & .971 \\
\hline Autonomy & $\begin{array}{l}49.94 \\
(8.9)\end{array}$ & $\begin{array}{l}50.58 \\
(8.7)\end{array}$ & $\begin{array}{l}49.17 \\
(9.2)\end{array}$ & 1.311 & .254 \\
\hline Dominance & $\begin{array}{l}57.26 \\
(9.6)\end{array}$ & $\begin{array}{r}57.83 \\
(10.1)\end{array}$ & $\begin{array}{l}56.57 \\
(9.0)\end{array}$ & .896 & .345 \\
\hline Endurance & $\begin{array}{l}57.20 \\
(9.7)\end{array}$ & $\begin{array}{l}57.65 \\
(9.8)\end{array}$ & $\begin{array}{l}56.65 \\
(9.6)\end{array}$ & .550 & .459 \\
\hline Exhibition & $\begin{array}{l}55.39 \\
(9.6)\end{array}$ & $\begin{array}{l}55.55 \\
(9.9)\end{array}$ & $\begin{array}{l}55.19 \\
(9.3)\end{array}$ & .074 & .787 \\
\hline Harmavoidance & $\begin{array}{l}50.40 \\
(9.3)\end{array}$ & $\begin{array}{l}50.81 \\
(9.3)\end{array}$ & $\begin{array}{l}49.91 \\
(9.3)\end{array}$ & .497 & .482 \\
\hline Impulsivity & $\begin{array}{l}52.37 \\
(9.9)\end{array}$ & $\begin{array}{r}53.25 \\
(10.0)\end{array}$ & $\begin{array}{l}51.30 \\
(9.8)\end{array}$ & 2.020 & .157 \\
\hline Nurturance & $\begin{array}{l}55.41 \\
(9.2)\end{array}$ & $\begin{array}{l}55.22 \\
(9.2)\end{array}$ & $\begin{array}{l}55.64 \\
(9.2)\end{array}$ & .113 & .737 \\
\hline Order & $\begin{array}{r}54.69 \\
(11.5)\end{array}$ & $\begin{array}{r}53.88 \\
(12.1)\end{array}$ & $\begin{array}{r}55.67 \\
(10.8)\end{array}$ & 1.269 & .261 \\
\hline Play & $\begin{array}{l}56.11 \\
(8.9)\end{array}$ & $\begin{array}{l}55.73 \\
(8.4)\end{array}$ & $\begin{array}{l}56.57 \\
(9.6)\end{array}$ & .454 & .501 \\
\hline Social Recognition & $\begin{array}{l}52.31 \\
(9.5)\end{array}$ & $\begin{array}{l}52.93 \\
(9.7)\end{array}$ & $\begin{array}{l}51.55 \\
(9.4)\end{array}$ & 1.102 & .295 \\
\hline Understanding & $\begin{array}{l}47.65 \\
(9.1)\end{array}$ & $\begin{array}{l}47.66 \\
(8.7)\end{array}$ & $\begin{array}{l}47.65 \\
(9.6)\end{array}$ & .000 & .998 \\
\hline
\end{tabular}

Standard deviations in parentheses. 